\title{
Study on Cross-Cultural Adaptability of Foreign Students Coming to Yunnan: Based on the Cultural Intelligence Perspective
}

\author{
Haibin Yang* \\ School of International Business \\ Yunnan University of Finance and Economics \\ Kunming, China \\ haibinyoung@foxmail.com
}

\author{
Haoxin Lv \\ School of International Business \\ Yunnan University of Finance and Economics \\ Kunming, China \\ 1057748474@qq.com
}

\begin{abstract}
At present, the number of foreign students coming to China in Yunnan accounts for about $4 \%$ of the number of Chinese students. However, among the students from Yunnan universities, the cross-cultural adaptation of international students is a topic that has received little attention. Based on the theory of cultural intelligence, this paper conducts a case study on the cross-cultural adaptation of foreign students in Yunnan, and obtains the first-hand adaptability data of college students in Yunnan through the mainstream field survey method in the West, and then combines the cultural intelligence. Table and SPSS data analysis, on the one hand, explores the cross-cultural adaptability of foreign students, on the other hand, it solves the cross-cultural adaptation problem of foreign students from the perspective of cultural intelligence, and proposes relevant theories for the management and education of foreign students in Yunnan. With feasibility suggestions, help colleges and universities to develop better policies.
\end{abstract}

Keywords: foreign students in Yunnan, cross-cultural adaptability, cultural intelligence

\section{INTRODUCTION}

Nowadays, many countries pay more attention to the importance of international students in order to promote their economic development, compete for international talents, enhance the international competitiveness of higher education, and strengthen international exchanges and cultural communication. In this context, China, as a rising power, is becoming the largest destination for study abroad in Asia with its unique charm and preferential policies for international students.

However, due to different countries, this will greatly affect whether overseas students are willing to study or even live in China.

In cross-cultural adaptability, the theory of cultural intelligence plays a crucial role in the cross-cultural adaptability of individuals.

The theory of cultural intelligence mainly includes four factors: (1) the individual's understanding and adaptability to new cultural knowledge -- meta-cognitive cultural

*Corresponding author intelligence.(2) the ability of individuals to master different cultural knowledge -- cognitive cultural intelligence.(3) Whether the individual has the willingness to actively understand the new cultural environment and actively deal with the problems encountered in the new cultural environment - motivational cultural intelligence.(4) individuals in different cultural environment when the exchange, whether can use the ability to communicate behavior cultural intelligence.Therefore, from the perspective of cultural intelligence, we will further improve the management system and relevant literature of foreign students in colleges and universities in Yunnan, so as to help foreign students successfully go through the adjustment period of acculturation.

\section{ANALYSIS OF CROSS-CULTURAL ADAPTABILITY OF OVERSEAS STUDENTS IN YUNNAN}

Cross-cultural adaptability has a great impact on whether overseas students are willing to go to Yunnan or continue to study and even live in Yunnan.Therefore, whether the students in Yunnan have strong cross-cultural adaptability, and how Yunnan University can help students adapt to life in Chinese schools, is whether Yunnan can attract international students to come, whether to retain the talents of international students to serve our country an important part.

In general, when international students come to Study in Yunnan, they generally go through four stages: the excitement period - - attracted by Yunnan culture, with curiosity to understand everything in Yunnan, cultural shock periodas the new environment and their previous life is very different, students will have frustration, anxiety, loneliness and other emotions Initial adjustment and adaptation period- When the students' psychology fluctuates, the students will begin to adjust their mentality to adapt to the new environment of life, and the — students have adapted to the life in Yunnan, and have the confidence to face the problems encountered in the life of Yunnan. 
Of course, in order to better understand the information about the cross-cultural adaptation period of Yunnan students and to better help students in Yunnan to better live, we use the SWOT method to make a detailed analysis of the crosscultural adaptation of foreign students in Yunnan.

TABLE I. SWOT ANALYSIS ON THE CROSS-CULTURAL DEVELOPMENT ENVIRONMENT OF

\begin{tabular}{|c|c|}
\hline Strengths & Weaknesses \\
\hline $\begin{array}{l}\text { First, The large number of } \\
\text { international students in Yunnan is } \\
\text { growing, which will be conducive to } \\
\text { the old students and new students in } \\
\text { Yunnan to help each other, faster to } \\
\text { adapt to cross-cultural life in Yunnan. } \\
\text { Secondly, Yunnan is bordered by a } \\
\text { large number of South and Southeast } \\
\text { Asian countries, and international } \\
\text { students from these border countries } \\
\text { have a certain understanding of the } \\
\text { culture of Yunnan. } \\
\text { Third,Yunnan universities and } \\
\text { many South Asian and Southeast Asian } \\
\text { countries have good relations of } \\
\text { cooperation, conducive to help students } \\
\text { in cross-cultural life to better develop. }\end{array}$ & $\begin{array}{l}\text { First, according to the statistical } \\
\text { survey and related literature on } 134 \\
\text { students from Yunnan, it is concluded } \\
\text { that the Chinese language level of } \\
\text { international students in Yunnan is } \\
\text { generally low, which will be a major } \\
\text { obstacle to the cross-cultural } \\
\text { development of international students. } \\
\text { Second, students in Yunnan in } \\
\text { colleges and universities because of } \\
\text { cultural differences, can not quickly } \\
\text { form a better relationship with teachers } \\
\text { and students in Yunnan, resulting in } \\
\text { foreign students in the cultural conflict } \\
\text { in the period of cultural shock and } \\
\text { adjustment at a disadvantage. } \\
\text { Third, the management of } \\
\text { international students in most colleges } \\
\text { and universities in Yunnan is still in the } \\
\text { gradual standardization, which is a } \\
\text { major disadvantage in the cross-cultural } \\
\text { development of colleges and } \\
\text { universities in Yunnan, which will } \\
\text { greatly affect the cross-cultural } \\
\text { adaptation of international students. }\end{array}$ \\
\hline Opportunities & Threats \\
\hline $\begin{array}{l}\text { First, "bridgehead" strategy and } \\
\text { "The Belt And Road Initiative" strategy } \\
\text { create more favorable conditions for } \\
\text { overseas students to further study and } \\
\text { develop in Yunnan universities. } \\
\text { Second, Colleges and universities } \\
\text { in Yunnan are strengthening the } \\
\text { construction of international } \\
\text { competitiveness in education, which } \\
\text { will help international students to live } \\
\text { and study better in Yunnan. }\end{array}$ & $\begin{array}{l}\text { First, In the cross-cultural impact, } \\
\text { the students of Yunnan will face the } \\
\text { process of the whole adjustment and } \\
\text { adaptation period of the period of } \\
\text { cultural shock - the initial adjustment } \\
\text { and adaptation period -- the period of } \\
\text { psychological isolation. } \\
\text { Second, There are certain } \\
\text { differences between international } \\
\text { students and Chinese students in their } \\
\text { personal behavior, way of thinking and } \\
\text { living habits, which bring great } \\
\text { challenges to the cross-cultural } \\
\text { adaptation of international students in } \\
\text { Yunnan. }\end{array}$ \\
\hline
\end{tabular}

To sum up, Yunnan students have better development space and policy support in cross-cultural adaptation, but in terms of current form, due to the differences in culture and the imperfection of relevant policies in universities, there are still major problems in the face of cultural impact in cross-cultural adaptation. Therefore, how to use and further expand the advantages and opportunities of cross-cultural development of international students to reduce the disadvantages of crosscultural development of international students and correctly handle the challenges of cross-cultural development is very important.

\section{CROSS-CULTURAL MANAGEMENT ANALYSIS OF FOREIGN STUDENTS IN YUNNAN}

From an economic point of view, the entry of a large number of international students has made a great contribution to the economic development of Yunnan. However, from the cultural point of view, with the entry of international students, the friction and collision between different cultures in Yunnan University will become a new problem in the management of colleges and universities in Yunnan. The management object of the university representative is changed from domestic students to international students, and its management environment is also changed to the management environment has also shifted to international multiculturalism, so with the passage of time, the management policy of Yunnan university will pay more and more attention to the integration of different cultures will become a new trend.

At the same time, we get from the relevant literature and field examination: First, the overall level of Chinese language improvement of international students at Kunming University of Higher Education in Yunnan is slightly higher than that of other universities, but the overall level of Chinese language of foreign students in Yunnan is lower, and in the discussion on how to improve the Chinese level of international students, Most studies advocate a large number of Chinese training for international students, but lack of research to promote more active study by improving the psychological quality of international students Chinese.Second, in the face of cultural shock period and cultural adaptation adjustment period, Yunnan students have a larger problem, and often because of these two aspects of the phenomenon of leaving the school. Third, the management policy of international students in most colleges and universities in Yunnan is still under construction, and the policy on helping students to better cross-cultural life is still being discussed, and most of the current policies of colleges and universities lack the attention to the psychological quality of international students.Fourth, in the aspect of helping students in Yunnan to better adapt to cross-cultural life, whether in literature research or policymaking, it is still rare to analyze how to improve the individual psychological ability of international students, so as to help students better adapt to cross-cultural life as a whole. This also leads to the management of international students often miss a lot of important details, resulting in international students in the new environment in the process of adaptation is hindered.

Therefore, from the study of individual cross-cultural psychology of international students, on the one hand, to further improve the relevant policies and related assistance methods to help students better through the cross-cultural adaptation period, on the other hand, to further improve the management system of international students in Yunnan , will have a positive significance.

\section{DATA DESCRIPTION}

In order to study the rationality, we used a field investigation method combined with the cultural intelligence table. So we in the questionnaire on the one hand focused on the gender of international students, time in China, academic 
performance in China, experience abroad, the number of relatives in China to investigate. On the other hand, we draw on Xiao Fen and Zhang Jianmin's revised post-cultural intelligence table to design, and form a questionnaire consisting of meta-cognitive cultural intelligence, cognitive cultural intelligence, motivational cultural intelligence and behavioral cultural intelligence to form a total of 20 questions to investigate. Finally, use SPSS to statistically analyze the questionnaire data to further enhance the rationality and scientific of the conclusions

Over a period of one month, we distributed 180 questionnaires through different channels and collected them to 132 , with an efficiency of $73.3 \%$.

\section{CALCULATION RESULTS AND ANALYSIS}

First: Factors affecting the cultural intelligence of international students.

From the table. II independent sample T test result shows that "been abroad" and "haven't been abroad" in the "cultural intelligence" on the independent sample $\mathrm{T}$ test $\mathrm{T}$ value equal to 3.258 , significant probability value $=0.001, \mathrm{P}<0.05$, reached significant level, to explain "been abroad" and "haven't been abroad" significant differences on "cultural intelligence", and been abroad cultural intelligence level is higher, shows whether been abroad has significant positive influence on cultural intelligence;"Have relatives in China" and "no relatives in China" on the "cultural intelligence" independent sample $\mathrm{T}$ test $\mathrm{T}$ value equal to 3.739 , significant probability value $=0.000, \mathrm{P}<0.05$, reached significant level, "have relatives in China" and "no relative in China's" significant differences on "cultural intelligence", and have relatives in China's cultural intelligence level is higher, that have relatives in China has significant positive influence on cultural intelligence.

From the correlation analysis results in table.III, it can be seen that the probability values of the significant test of the correlation coefficient between time, knowledge level and Cultural intelligence in China are all less than 0.05, indicating that the two variables are significantly correlated with Cultural intelligence, Preliminary shows that these two variables have a significant impact on cultural intelligence.

From the table. The IV regression analysis result, the time in China, the understanding degree of multiple correlation coefficient is 0.783 , the square of the multiple correlation coefficient for. 614, said two independent variables can explain $61.4 \%$ of the variance of "cultural intelligence" variables, variance of significance test $F$ value is 102.426, the significance test $\mathrm{p}$ value is less than 0.001 , according to regression model of whole explain variance reached significant level.In the regression model, the regression coefficient test probability values of the two variables are all less than 0.001, and the standardized regression coefficients are all greater than 0 , indicating that the two independent variables have a significant positive impact on "Cultural intelligence".
TABLE II.

\begin{tabular}{|c|c|c|c|c|c|c|}
\hline $\begin{array}{r}\text { Depend } \\
\text { ent variables }\end{array}$ & $\begin{array}{l}\text { Argum } \\
\text { ents }\end{array}$ & & $\begin{array}{l}\text { Ave } \\
\text { rage }\end{array}$ & $\begin{array}{c}\text { Stan } \\
\text { dard } \\
\text { deviation }\end{array}$ & $\mathrm{t}$ & $\mathrm{P}$ \\
\hline \multirow[t]{4}{*}{$\begin{array}{r}\text { Cultural } \\
\text { intelligence }\end{array}$} & \multirow{2}{*}{$\begin{array}{l}\text { Have } \\
\text { you ever } \\
\text { been } \\
\text { abroad? }\end{array}$} & es $^{\mathrm{Y}}$ & 1.509 & .313 & \multirow{2}{*}{$\begin{array}{c}- \\
3.258\end{array}$} & \multirow{2}{*}{.001} \\
\hline & & $0^{\mathrm{N}}$ & 1.703 & .347 & & \\
\hline & \multirow{2}{*}{$\begin{array}{c}\text { Are } \\
\text { there any } \\
\text { relatives in } \\
\text { China? }\end{array}$} & & 1.444 & .320 & \multirow{2}{*}{$\begin{array}{c}- \\
3.739\end{array}$} & \multirow{2}{*}{.000} \\
\hline & & $0^{\mathrm{N}}$ & 1.658 & .322 & & \\
\hline
\end{tabular}

TABLE III.

\begin{tabular}{|l|l|l|l|l|}
\hline & & $\begin{array}{l}\text { Cultural } \\
\text { intelligence }\end{array}$ & $\begin{array}{l}\text { TIME SPENT IN } \\
\text { CHINA }\end{array}$ & $\begin{array}{l}\text { HOW MUCH DO I } \\
\text { KNOW ABOUT } \\
\text { CHINA }\end{array}$ \\
\hline \multirow{2}{*}{$\begin{array}{l}\text { Cultural } \\
\text { intelligence }\end{array}$} & Correlation factor & & & \\
\cline { 2 - 5 } & $\begin{array}{l}\text { Significant (two- } \\
\text { sided) }\end{array}$ & & & \\
\hline $\begin{array}{l}\text { Time spent in } \\
\text { China }\end{array}$ & Correlation factor & $.487^{* *}$ & & \\
\cline { 2 - 5 } & $\begin{array}{l}\text { Significant (two- } \\
\text { sided) }\end{array}$ & .000 & & \\
\hline \multirow{2}{*}{$\begin{array}{l}\text { How much do I } \\
\text { know about } \\
\text { China }\end{array}$} & Correlation factor & $.756^{* *}$ & $.396^{* *}$ & \\
\cline { 2 - 5 } & $\begin{array}{l}\text { Significant } \\
\text { (two-sided) }\end{array}$ & .000 & .000 & \\
\hline
\end{tabular}

TABLE IV.

\begin{tabular}{|c|c|c|c|c|c|c|c|c|}
\hline $\begin{array}{l}\text { THE } \\
\text { DEPENDEN } \\
\text { T } \\
\text { VARIABLE }\end{array}$ & $\begin{array}{l}\text { ARGUME } \\
\text { NTS }\end{array}$ & $\begin{array}{l}\text { MULTIPLE } \\
\text { CORRELATI } \\
\text { ON } \\
\text { COEFFICIE } \\
\text { NTS }\end{array}$ & $\begin{array}{l}\text { DECISI } \\
\text { ON } \\
\text { FACTO } \\
\text { R R }\end{array}$ & $\begin{array}{l}\text { INCREA } \\
\text { SE D'R }\end{array}$ & F & $\mathrm{Sig}$ & B & $\begin{array}{c}\text { Bet } \\
\text { a }\end{array}$ \\
\hline \multirow[t]{2}{*}{$\begin{array}{l}\text { CuLtuRAL } \\
\text { INTELLIGE } \\
\text { NCE }\end{array}$} & $\begin{array}{l}\text { TIME TO } \\
\text { LIVE } \\
\text { CHINA }\end{array}$ & \multirow[b]{2}{*}{.783} & \multirow[b]{2}{*}{.614. } & \multirow[b]{2}{*}{.608} & \multirow[b]{2}{*}{$\begin{array}{c}102.4 \\
26\end{array}$} & $\begin{array}{c}.00 \\
0\end{array}$ & .119 & $\begin{array}{l}.22 \\
3\end{array}$ \\
\hline & $\begin{array}{l}\text { How } \\
\text { MUCH DO } \\
\text { I KNOW } \\
\text { ABOUT } \\
\text { CHINA }\end{array}$ & & & & & $\begin{array}{c}.00 \\
0\end{array}$ & $\begin{array}{c}1.00 \\
2\end{array}$ & $\begin{array}{c}.66 \\
8\end{array}$ \\
\hline
\end{tabular}


Second: The Relationship between Cultural Intelligence and Cross-Cultural

In the cross-cultural adaptation of international students, the psychological adaptation, social and cultural adaptation, academic adaptation and cross-cultural adaptation are closely related, so in order to get better results, we further analyze the relationship between cultural intelligence and these four aspects.

Can be seen from table $\mathrm{V}$ is the result of regression analysis, social intelligence meta-cognition, cognition, motivation, behavior of the four variables of multiple correlation coefficient is 0.764 , the square of the multiple correlation coefficient for. 584, said the four independent variables can explain "mental adaptation" variable is $86.5 \%$ of the variance, variance of significance test $F$ value is 203.015, the significance test $\mathrm{p}$ value is less than 0.001 , according to regression model of whole explain variance reached significant level.In the regression model, the regression coefficient test probability values of the four variables are all less than 0.001, and the standardized regression coefficients are all greater than 0 , indicating that the four independent variables have a significant positive impact on "psychological adaptation".From the perspective of the standardized regression coefficient, the absolute value of the standardized regression coefficient of motivation is the largest, indicating that it has the most significant influence on psychological adaptation.

From the table.VI of the regression analysis results can be seen that the meta-cognitive, cognitive social intelligence, motivation, behavior, four variables of multiple correlation coefficient is 0.956 , the square of the multiple correlation coefficient for. 914, said the four independent variables can explain $91.4 \%$ of the variance of "social cultural adaptation" variables and variance of significance test of the $F$ value is 337.087 , the significance test $p$ value is less than 0.001 , said regression model as a whole explain variance at significant level.In the regression model, the regression coefficient test probability values of the four variables are all less than 0.001 , and the standardized regression coefficients are all greater than 0 , indicating that the four independent variables have a significant positive impact on social acculturation.From the perspective of standardized regression coefficient, the absolute value of standardized regression coefficient of metacognition, cognition and behavior is relatively large, indicating that these three variables have more significant influence on social acculturation.

From the table. The VII of the regression analysis results can be seen that the social intelligence of meta-cognition, cognition, motivation, behavior, four variables of multiple correlation coefficient is 0.735 , the square of the multiple correlation coefficient for. 541, said the four independent variables can explain $54.1 \%$ of the variance of "social cultural adaptation" variables and variance of significance test of the F value is 37.381 , the significance test $p$ value is less than 0.001 , according to regression model of whole explain variance reached significant level.In the regression model, the regression coefficient test probability values of the four variables are all less than 0.001 , and the standardized regression coefficients are all greater than 0 , indicating that the four independent variables have a significant positive impact on academic adaptation.From the perspective of standardized regression coefficient, the absolute value of standardized regression coefficient of meta-cognition, cognition and behavior is relatively large, indicating that these three variables have a more significant impact on academic adaptation.

TABLE V.

\begin{tabular}{|c|c|c|c|c|c|c|c|c|}
\hline $\begin{array}{l}\text { THE } \\
\text { DEPENDE } \\
\text { NT } \\
\text { VARIABLE }\end{array}$ & $\begin{array}{l}\text { THE } \\
\text { INDEPE } \\
\text { NDENT } \\
\text { VARIAB } \\
\text { LES }\end{array}$ & $\begin{array}{l}\text { MULTIP } \\
\text { LE } \\
\text { CORREL } \\
\text { ATION } \\
\text { COEFFIC } \\
\text { IENTS }\end{array}$ & $\begin{array}{l}\text { DECISIO } \\
\mathrm{N} \\
\text { COEFFICI } \\
\text { ENTR }^{2}\end{array}$ & $\begin{array}{l}\text { INCRE } \\
\text { ASED } \\
\Delta \mathrm{R}\end{array}$ & $\mathrm{F}$ & $\begin{array}{l}\mathrm{Si} \\
\mathrm{g} .\end{array}$ & B & $\begin{array}{l}\mathrm{Be} \\
\mathrm{ta}\end{array}$ \\
\hline \multirow[t]{4}{*}{$\begin{array}{l}\text { PSYCHOL } \\
\text { OGICAL } \\
\text { ADAPTATI } \\
\text { ON }\end{array}$} & $\begin{array}{l}\text { meta- } \\
\text { cognitio } \\
\mathrm{n}\end{array}$ & \multirow{4}{*}{.930} & \multirow{4}{*}{.865} & \multirow{4}{*}{.860} & \multirow{4}{*}{$\begin{array}{l}203 . \\
015\end{array}$} & $\begin{array}{l}.0 \\
00\end{array}$ & $\begin{array}{l}.2 \\
44\end{array}$ & $\begin{array}{l}.2 \\
59\end{array}$ \\
\hline & $\begin{array}{l}\text { Cogniti } \\
\text { ve }\end{array}$ & & & & & $\begin{array}{l}.0 \\
25\end{array}$ & $\begin{array}{l}.0 \\
83\end{array}$ & $\begin{array}{l}.1 \\
21\end{array}$ \\
\hline & $\begin{array}{l}\text { Motivat } \\
\text { ion }\end{array}$ & & & & & $\begin{array}{l}.0 \\
00\end{array}$ & $\begin{array}{l}.1 \\
96\end{array}$ & $\begin{array}{l}.3 \\
80\end{array}$ \\
\hline & $\begin{array}{l}\text { Behavio } \\
\mathrm{r}\end{array}$ & & & & & $\begin{array}{l}.0 \\
00\end{array}$ & $\begin{array}{l}.2 \\
93\end{array}$ & $\begin{array}{l}.3 \\
70\end{array}$ \\
\hline
\end{tabular}

TABLE VI

\begin{tabular}{|c|c|c|c|c|c|c|c|c|}
\hline $\begin{array}{l}\text { THE } \\
\text { DEPENDE } \\
\text { NT } \\
\text { VARIABLE }\end{array}$ & $\begin{array}{l}\text { THE } \\
\text { INDEPE } \\
\text { NDENT } \\
\text { VARIAB } \\
\text { LES }\end{array}$ & $\begin{array}{l}\text { MULTIP } \\
\text { LE } \\
\text { CORREL } \\
\text { ATION } \\
\text { COEFFIC } \\
\text { IENTS }\end{array}$ & $\begin{array}{l}\text { DECISIO } \\
\mathrm{N} \\
\text { COEFFICI } \\
\text { ENTR }^{2}\end{array}$ & $\begin{array}{l}\text { INCRE } \\
\text { ASED } \\
\Delta \mathrm{R}\end{array}$ & $\mathrm{F}$ & $\begin{array}{l}\mathrm{Si} \\
\mathrm{g} .\end{array}$ & B & $\begin{array}{l}\mathrm{Be} \\
\mathrm{ta}\end{array}$ \\
\hline \multirow[t]{4}{*}{$\begin{array}{l}\text { SOCIOCUL } \\
\text { TURAL } \\
\text { ADAPTATI } \\
\text { ON }\end{array}$} & $\begin{array}{l}\text { meta- } \\
\text { cognitio } \\
n\end{array}$ & \multirow{4}{*}{.956} & \multirow{4}{*}{.914} & \multirow{4}{*}{.911} & \multirow{4}{*}{$\begin{array}{l}337 . \\
087\end{array}$} & $\begin{array}{l}.0 \\
00\end{array}$ & $\begin{array}{r}.2 \\
90\end{array}$ & $\begin{array}{r}.2 \\
95\end{array}$ \\
\hline & $\begin{array}{l}\text { Cogniti } \\
\text { ve }\end{array}$ & & & & & $\begin{array}{l}.0 \\
00\end{array}$ & $\begin{array}{l}.2 \\
26\end{array}$ & $\begin{array}{l}.3 \\
17\end{array}$ \\
\hline & $\begin{array}{l}\text { Motivat } \\
\text { ion }\end{array}$ & & & & & $\begin{array}{l}.0 \\
00\end{array}$ & $\begin{array}{l}.1 \\
42\end{array}$ & $\begin{array}{l}.2 \\
66\end{array}$ \\
\hline & $\begin{array}{l}\text { Behavio } \\
\mathrm{r}\end{array}$ & & & & & $\begin{array}{l}.0 \\
00\end{array}$ & $\begin{array}{l}.2 \\
28\end{array}$ & $\begin{array}{l}.2 \\
76\end{array}$ \\
\hline
\end{tabular}


TABLE VII

\begin{tabular}{|c|c|c|c|c|c|c|c|c|}
\hline $\begin{array}{l}\text { THE } \\
\text { DEPEND } \\
\text { ENT } \\
\text { VARIAB } \\
\text { LE }\end{array}$ & $\begin{array}{l}\text { THE } \\
\text { INDEPEN } \\
\text { DENT } \\
\text { VARIABL } \\
\text { ES }\end{array}$ & $\begin{array}{l}\text { MULTIP } \\
\text { LE } \\
\text { CORREL } \\
\text { ATION } \\
\text { COEFFICI } \\
\text { ENTS }\end{array}$ & $\begin{array}{l}\text { DECISION } \\
\text { COEFFICI } \\
\text { ENTR }^{2}\end{array}$ & $\begin{array}{l}\text { INCRE } \\
\text { ASED } \\
\Delta \mathrm{R}\end{array}$ & F & $\begin{array}{l}\mathrm{Si} \\
\mathrm{g} .\end{array}$ & B & $\begin{array}{l}\mathrm{Be} \\
\text { ta }\end{array}$ \\
\hline \multirow[t]{4}{*}{$\begin{array}{l}\text { ACADE } \\
\text { MIC } \\
\text { ADAPTA } \\
\text { TION }\end{array}$} & $\begin{array}{l}\text { meta- } \\
\text { cognitio } \\
\mathrm{n}\end{array}$ & \multirow{4}{*}{.735} & \multirow{4}{*}{.541} & \multirow{4}{*}{.526} & \multirow{4}{*}{$\begin{array}{c}37.3 \\
81\end{array}$} & $\begin{array}{l}.0 \\
04\end{array}$ & $\begin{array}{l}.4 \\
45\end{array}$ & $\begin{array}{l}.2 \\
46\end{array}$ \\
\hline & $\begin{array}{l}\text { Cognitiv } \\
\text { e }\end{array}$ & & & & & $\begin{array}{l}.0 \\
16\end{array}$ & $\begin{array}{l}.3 \\
19\end{array}$ & $\begin{array}{l}.2 \\
43\end{array}$ \\
\hline & $\begin{array}{l}\text { Motivati } \\
\text { on }\end{array}$ & & & & & $\begin{array}{l}.0 \\
38\end{array}$ & $\begin{array}{l}.1 \\
49\end{array}$ & $\begin{array}{l}.1 \\
51\end{array}$ \\
\hline & $\begin{array}{l}\text { Behavio } \\
\mathrm{r}\end{array}$ & & & & & $\begin{array}{l}.0 \\
00\end{array}$ & $\begin{array}{l}.3 \\
62\end{array}$ & $\begin{array}{l}.2 \\
38\end{array}$ \\
\hline
\end{tabular}

\section{CONCLUSION}

Behavioral cultural intelligence and meta-cognitive cultural intelligence:

First, the university should encourage foreign students to learn Chinese actively so that their Chinese level can be improved.

Second, we should build an exchange circle for international students to enhance the interaction between them and Chinese teachers and students.

International students with high behavioral cultural intelligence have good behavior elasticity, can target different situations, different objects, use excellent self-representation, rich language behavior and suitable body language and other elements to better cross-cultural exchange, so that they can get the favor of others, so that they can better adapt to crosscultural exchanges, adapt to cross-cultural life. At the same time, the students with high cognitive cultural intelligence have better adaptability and communication adaptability, and have a higher ability to think strategically, so that their life in the study abroad countries is better.

Combining large amounts of data and surveys, we found two problems:1. Although most of the students in Yunnan University are willing to communicate with Chinese teachers and students, due to language barriers, many students are unable to communicate with Chinese teachers and students in depth, resulting in students to Chinese culture, social environment, As well as the school environment and related policies can only be recognized through the change of the surrounding environment and simple communication with Chinese teachers and students, this kind of limited understanding will seriously hinder the process of Yunnan university students to adapt to the life of Yunnan University. 2. Due to the complexity of Chinese characters, in the Chinese classroom, international students still can't fully adapt to
Chinese teaching. They only stay in the extremely simple knowledge of the classroom content, and can't understand the deep knowledge content in the teacher's classroom. We can see that the degree of Chinese language of international students and the degree of interaction between international students and Chinese teachers and students have a major impact on the cross-cultural life of international students. Therefore, we can improve the Chinese level of international students through the exchange of courses between Chinese and foreign students and through forms and activities. Create a circle of communication between international students and Chinese teachers and students, so that international students can further integrate into the new environment, and have a stronger ability to adapt to school life and familiar with different cultural values. These methods can also enable international students to improve their behavioral cultural intellectual ability and meta-cognitive cultural intellectual ability, help foreign students to carry out strategic thinking about their own development in their own schools, better respond to academic pressure, and be able to Deeper exchanges with Chinese students or teachers of the school to further understand and adapt to the culture of the school, and make the school more convenient in cross-cultural management.

\section{Cognitive cultural intelligence:}

Strengthen the ability of foreign students to master the knowledge theory of new culture. Cognitive cultural intelligence refers to the ability of individuals to master the knowledge theory of new culture. This requires international students from China to have a deep understanding of Chinese laws, beliefs, and social systems. However, in the survey, the vast majority of Chinese students studying in China have only a half-baked understanding of China's legal system, which will greatly reduce the cognitive and intellectual intelligence of Chinese students, resulting in students of different degrees of difficulty in Chinese life. This can easily lead to illegal employment, illegal driving, illegal residence or the emergence of ideological problems among international students, which makes the school encounter more difficulties in managing international students. Therefore, it is extremely important to improve the cognitive intelligence of foreign students by strengthening the laws, beliefs, and social systems of Chinese students.

\section{Motivation cultural intelligence:}

First, enhance the psychological capital of international students. Improving the motivation and cultural intelligence of international students will help international students' cross-cultural psychological and social adaptation and bring more convenience to school management. When a student with a strong motivation and culture is in a new culture, he will get more rewards in a shorter time than most of the students who came to the new environment in the same batch, because the students with strong motivation and intellectual intelligence will be brave. Accept the new environment, set the process of adapting to the new culture as its goal, actively maintain the cultural norms of the new environment, and learn 
the culture of the new environment.Among them, motivational cultural intelligence is closely related to psychological capital. People with strong psychological capital have stronger self-confidence and will have stronger motivation and cultural intelligence. When international students have strong confidence in adapting to new cultures, international students will be more active in thinking about the social environment of the new environment and learning how to deal with different cultural scenarios. At the same time, international students will be more active in learning new cultures.Therefore, colleges and universities in Yunnan pay attention to the construction of psychological capital of foreign students, improve the motivation and cultural intelligence of foreign students, and arrange psychological doctors for international students to treat foreign students who have major obstacles during cross-cultural adaptation. Or arrange for senior students to help lower grades of international students, so that international students can adapt to new life.

Second, Further deepen the campus management Internet. In cross-cultural communication, the stronger the sense of happiness and satisfaction of international students in their schools, the stronger their motivation in cultural intelligence, the stronger their cultural and intellectual abilities, as this will motivate international students to become more active in adapting to school life and learning in different schools. Lifestyle habits.However, according to the survey of a large number of international students, there are always complicated processes in the study of campus life business or school business in Yunnan colleges and universities. As a result, the happiness of foreign students in college life is reduced, which affects the improvement of students' motivation and cultural intelligence. In order to enhance students' motivation and cultural intelligence, management departments can use modern information technology to create a variety of comprehensive communication platforms for international students. It is easier and faster for foreign students to handle related business, making it easier for international students to live in cross-cultural adaptation.

\section{Motivation and meta-cognitive intelligence:}

As an integral part of the overall international students, individual cultural students have a great influence on the management of foreign students. Motivating cultural intelligence and meta-cognitive cultural intelligence are important factors in the management of international students. Because the higher the motivation, cultural intelligence and meta-cognitive culture and intelligence of foreign students in cross-cultural management, the easier it is for foreign students to accept the new environment, and the more active the students are, the more sensitive they are to the new environment. Different characteristics of culture, and then understand the background and environment of the culture of the country in which they live, thus consciously correcting the knowledge model of the country or group culture, and thinking about the rules of interaction with the country, and finally adjusting themselves in the country and Acting with others and getting along with others. This will reduce the conflicts caused by cultural differences in the management of international students, which greatly facilitates the management of international students.

Therefore, universities in Yunnan can require international students to enjoy the same teaching resources through the same training programs and teaching objectives as Chinese students, so that foreign students can enjoy the same teaching resources. In addition, enhance the understanding of Chinese culture and Yunnan society. Let foreign students further understand and respect our management model. At the same time, it should pay attention to differential management. Because the cultural background, living habits, thinking style and language foundation of international students are different, schools should formulate a system that conforms to international students. Enable international students to live in a comfortable environment and improve their motivational cultural intelligence and meta-cognitive cultural intelligence.

\section{REFERENCES}

[1] Meredith Tharapos,Brendan T. O'Connell,Steven Dellaportas,Ilias Basioudis. Are accounting academics culturally intelligent?: An empirical investigation[J]. The British Accounting Review,2019,51(2)

[2] Lam,Cheung. Towards an understanding of the culturally intelligent behaviour of hotel service employees[J]. International Journal of Tourism Sciences,2018,18(3)

[3] Amirhosein GhaffarianHoseini,Rahinah Ibrahim,Mohd Nasir Baharuddin,Ali GhaffarianHoseini. Creating green culturally responsive intelligent buildings: Socio-cultural and environmental influences[J]. Intelligent Buildings International,2011,3(1).

[4] Lynn Imai,Michele J. Gelfand. The culturally intelligent negotiator: The impact of cultural intelligence (Cultura intelligence) on negotiation sequences and outcomes[J]. Organizational Behavior and Human Decision Processes, 2010,112(2). 